\title{
Solar XXI building: proof of concept or a concept to be proved?
}

\author{
Marta J. N. Oliveira Panao and Helder J. P. Gonçalves, \\ National Laboratory of Energy and Geology (LNEG), Estrada do Paço Lumiar, 22, \\ 1630-038 Lisbon, Portugal
}

\begin{abstract}
Solar XXI building is a low energy office building where passive and active solar strategies have been applied to reduce the use of energy for heating, cooling and lighting, combining also an extensive photovoltaic façade for electricity production. Solar XXI opened in 2006 and is considered a high efficient building, close to a net zero energy building (NZEB), where the difference between the energy consumed and that produced is $1 / 10^{\text {th }}$ of the energy consumed by a Portuguese standard new office building. Its design includes many energy efficiency concepts, such as a high insulated envelope, south sun exposure, windows external shading, photovoltaic panels heat recovery, ground-cooling system, daylighting, stack effect and cross ventilation. The solar gains of the windows and the effectiveness of shading devices were evaluated in order to correlate solar radiation, external and indoor air temperatures. It was also verified that amplitude-dampening of ground cooled air ranged between 5 and $8^{\circ} \mathrm{C}$, following the trend of the analytical solution for heat diffusion of a cylindrical air/soil heat-exchanger.
\end{abstract}

Keywords: passive office building, direct gain, ground-cooling system, photovoltaic façade, zero energy, monitoring

\section{Introduction}

Solar XXI building is a low energy office building with $1500 \mathrm{~m}^{2}$ of gross floor area located in Lisbon, Portugal $\left(38^{\circ} 46^{\prime} \mathrm{N}, 9^{\circ} 11^{\prime} \mathrm{W}\right)$. It integrates many of passive strategies to reduce the use of energy for heating, cooling and lighting, combining also an array of photovoltaic (PV) solar panels in the façade and at the parking lot for the production of electricity [1]. 
A passive solar building is a design concept mostly developed during the 70's, where the building follows diurnal and seasonal rhythms and is intimately related with its location [? ], following lessons from the past where building interacts actively with the natural elements (sun, wind, light, earth, water and vegetation).

The first passive solar office building in Europe was built in Cölbe (Germany) by the Wagner Co company, in September 1998, with a gross floor area of $2180 \mathrm{~m}^{2}$ [3]. In 2002, the biggest office building in Europe - Energon in Ulm (Germany) started operating [4]. This building has a net floor area of $8000 \mathrm{~m}^{2}$ and meets passive house standards with a total energy consumption of $81 \mathrm{kWh} / \mathrm{m}^{2}$ (by 2005). Afterwards, in successive years, passive office buildings were multiplied throughout Europe, namely Ghent Port Company and SD Worx in Kortrijk [5], both in Belgium, Energybase in Vienna (Austria), Etrium in Cologne (Germany), Le Volta in Paris (France).

The idea of this building was driven by a project developed during the 90 's, where the Portuguese passive solar buildings were characterized and cataloged [7]. Solar XXI started operating in 2006 and it has been intensively monitored ever since [8]. Its design includes many passive building concepts, such as apertures for direct solar gain, high insulated envelope high insulated envelope, windows shading, ground-cooling system, heat recovery, daylighting and natural ventilation (Table Tab:areas). Solar XXI building synthesizes past lessons and is projected to the future, toward the XXI century through an integrated approach of the best practices of energy efficiency in buildings.

During clear-sky winter days, the heat and light of the sun penetrates south offices. Additionally, heat from PV panels back is recovered and blown into office rooms. During summer, however, the sun altitude together with movable external blinds on south façade is the most effective prevention of overheating and these strategies are complemented by the cool air mechanically ventilated from ground-cooling pipes system. In the building's core, a large light well has the double function of collecting light and exhaust warm air from the inside. However, it is noteworthy that occupants play an important role on building thermal performance, because they are essential actors in controlling thermal comfort.

The successful integration of the PV panels in the façade is the main feature of the Solar XXI building, which merited a commendation of 2008 European Award on Building Integrated Solar Technology.

Considering that Solar XXI's design is based on the concept of integrating passive solar strategies for heating and cooling in a single building, in this 
paper, such integration is explored and analyzed in order to assess if the results obtained so far constitute a proof-of-concept, or else further research is required to improve it. The strategies analyzed here focus only on the direct gain, shading, ground-cooling system and natural ventilation stack effect.

\section{Passive concepts}

\subsection{Climate}

A key issue in the study of Solar XXI building conceptual design, in terms of the passive measures, is an accurate knowledge of its climate. Lisbon has a Mediterranean climate characterized by monthly average temperatures that swing between $10.6^{\circ} \mathrm{C}$ for the coldest month (January) and $22.6^{\circ} \mathrm{C}$ for the hottest (August). During summer, solar radiation is high, with daily values above $6.5 \mathrm{kWh} / \mathrm{m}^{2}$ and monthly sunshine hours above 300. Daily maximum average air temperature is around $28^{\circ} \mathrm{C}$; however extreme values of air temperatures higher than $35^{\circ} \mathrm{C}$ are not rare to occur. Winter is less severe because the daily average minimum temperature is between 8 and $10^{\circ} \mathrm{C}$ and annual rainfall is around $700 \mathrm{~mm}$ spread over 100 rainy days, mostly from October to May. Winter season lasts five months (from November until March) and heating degree-days are $860\left(18^{\circ} \mathrm{C}\right.$ of base temperature). This climate context is considered in the passive strategies that follows.

\subsection{Direct gain}

The direct gain concept is the simplest principle of solar buildings and consists of enlarging window areas in the south façade (for north hemisphere) so that winter solar energy is easily collected during daytime hours, providing these windows be properly shaded in cooling season. This strategy includes also the minimization of window areas in the east, west and north façades to the strictly necessary for natural lighting purposes.

In the Solar XXI building, office rooms are south oriented and have large windows providing heat and natural light to these rooms during the heating season (Fig. 2). The south façade is totally covered by windows and PV panels in nearly equal proportions (Fig. 1). Each window area is $4.4 \mathrm{~m}^{2}$ and the glazing system area (without frame) is $3.6 \mathrm{~m}^{2}$ corresponding to $22 \%$ of room floor area. South glazing ratio (percentage of glazing in a façade) is about $30 \%$ which promotes a balanced reduction of energy consumptions for heating, cooling and lighting together [9]. 


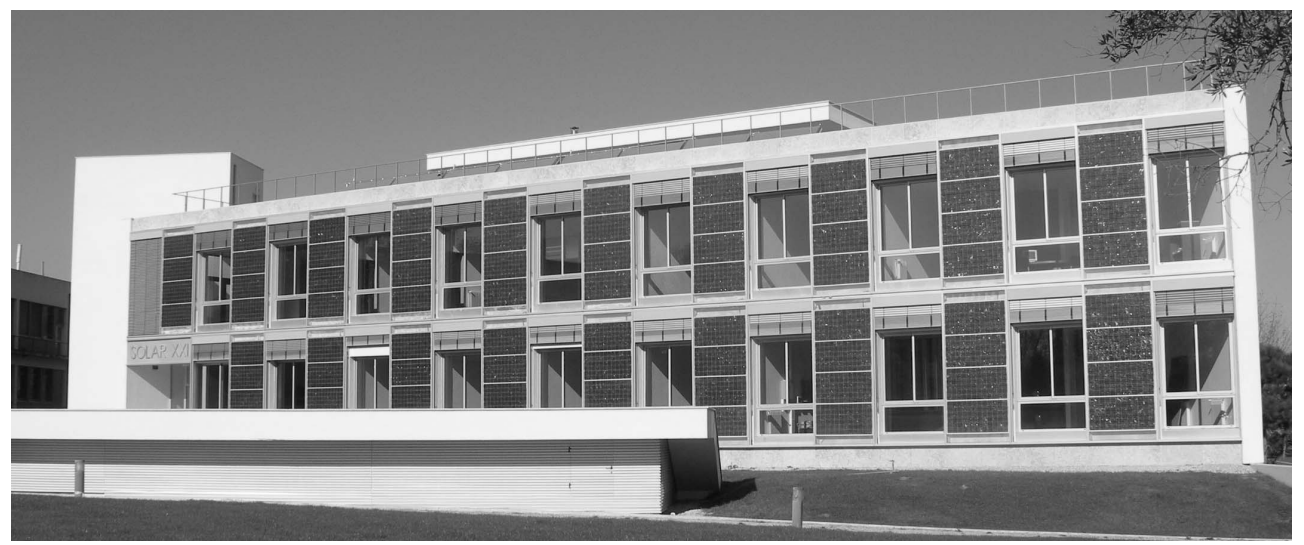

Figure 1: Direct gain and PV panels in south façade of Solar XXI building. Architects: Pedro Cabrito and Isabel Diniz.

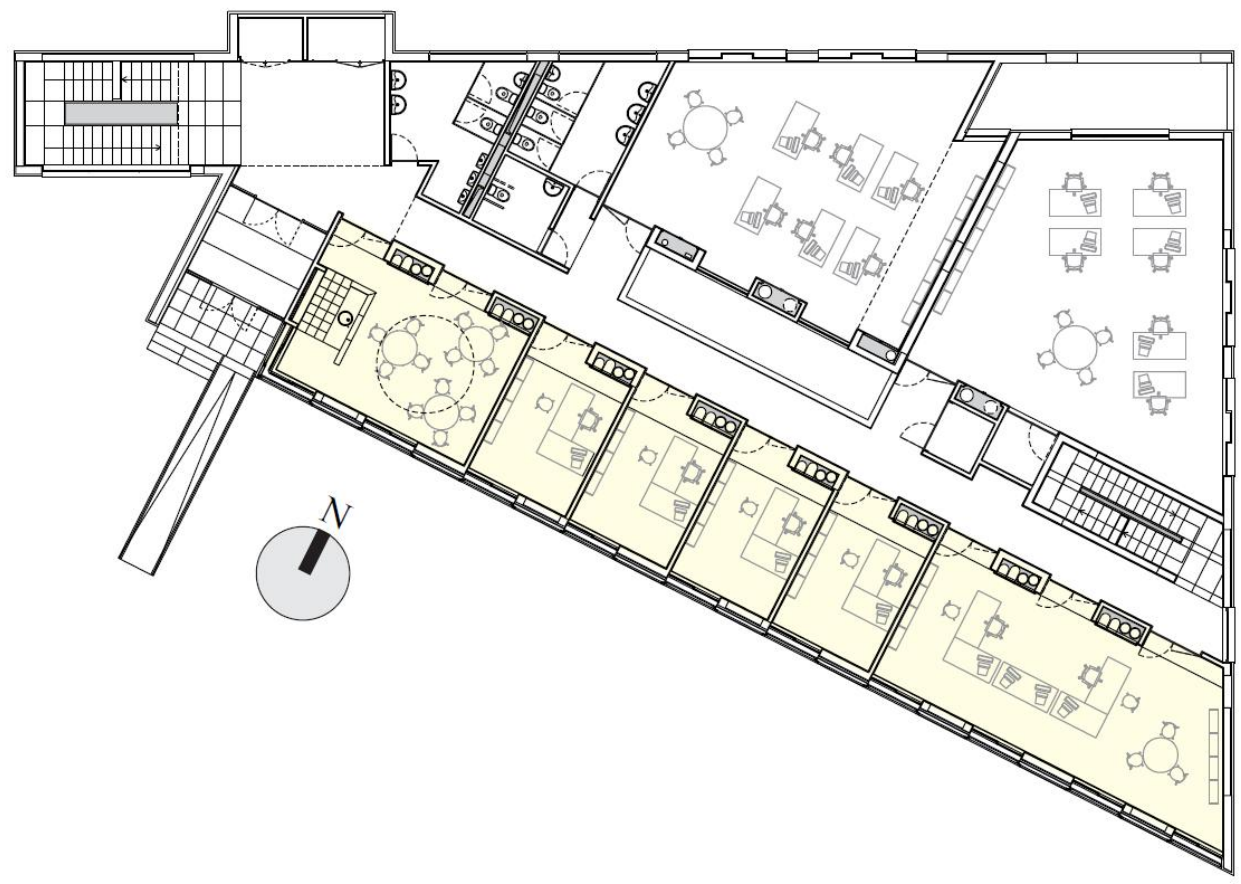

Figure 2: Ground floor plan: south oriented offices and north buffer zone. 
The remaining rooms located in the north part of the building, such as laboratories, auditoriums, bathrooms and occasional offices, constitute the building buffer zone (Fig. 2).

During winter sunny days, the total amount of energy collected by each direct gain system (window) is about $9.7 \mathrm{kWh}\left(2.7 \mathrm{kWh} / \mathrm{m}^{2}\right)$. Because floor is a light element in terms of thermal inertia, a small part of that energy is stored in built elements and the remaining part causes an increase of the sensible temperature during daytime hours which is a desirable behavior for an office building.

Table 1: Building characterization.

\begin{tabular}{lr}
\hline Building elements & area $\left(\mathrm{m}^{2}\right)$ \\
\hline gross floor area & 1500 \\
net floor area & 1030 \\
external walls & 400 \\
external roofs & 480 \\
semi-buried walls & 310 \\
ground floor & 470 \\
windows facing south & 80 \\
other windows & 100 \\
\hline
\end{tabular}

\subsection{Thermal insulation}

In solar buildings, thermal insulation is fundamental because it reduces thermal exchanges by conduction through the external envelope. This preventive strategy is useful in winter season by blocking heat (solar gains, internal gains and boiler produced) from leaving or, in summer season, from penetrating.

Solar XXI has hollow brick walls, externally insulated by $0.06 \mathrm{~m}$ of expanded polystyrene, the roof is externally insulated with $0.10 \mathrm{~m}$ of expanded and extruded polystyrene $(0.05+0.05 \mathrm{~m})$ and the ground floor is insulated by $0.10 \mathrm{~m}$ of expanded polystyrene (see U-values in Table 2). Thermal bridges are reduced in spite of the position of insulation elements. Double glazing is also used in order to reduce thermal losses by windows. The compactness of Solar XXI building, expressed by a surface-area-to-volume ratio of $0.33 \mathrm{~m}^{-1}$, is also an important characteristic to prevent thermal losses. Considering all these elements, a global conductance of $1670 \mathrm{~W} / \mathrm{K}$ is estimated for Solar XXI building. 
Table 2: U-value of building envelope.

\begin{tabular}{lr}
\hline external elements & U-value $\left(W /\left(m^{2} K\right)\right)$ \\
\hline wall & 0.45 \\
roof & 0.26 \\
floor & 0.55 \\
window & 4.50 \\
\hline
\end{tabular}

\subsection{Shading elements}

During summer season, in spite of natural lighting requirements, window shading is very important for preventing excessive solar gains. Preferably shading elements should be externally positioned, but different façades require different types of shading elements.

In this building, south windows have movable external Venetian blinds (Fig. 5), manually operated. Windows in other façades are shaded by internal and light roller shades. Some of them, including roof skylight, have adequate overhangs to cut direct summer radiation.

\subsection{Ground-cooling system}

No air conditioning system is used in Solar XXI building; however, for hot summer days, building users can turn on the ground-cooling system making use of the soil high thermal inertia. This system consists of two concrete pipes for each office room with a diameter of $0.30 \mathrm{~m}$ and a fan which blows the air into the office. The air is collected $15 \mathrm{~m}$ from the building (Fig. 3), travels at a depth of $4.6 \mathrm{~m}$ and is finally blown into the office room after crossing the pipes circuit (Fig. 4). Each fan flow rate is $200 \mathrm{~m}^{3} / \mathrm{h}$, resulting in a total of $8.7 \mathrm{ACH}$ of office volume. Soil temperature throughout the year varies from 13 to $19^{\circ} \mathrm{C}$; soil is therefore an excellent cooling source during summer season.

\subsection{Daylighting and natural ventilation}

In the middle of the building, there is a three-floor light well (Figs. 5 and 6) with the double function of natural lighting and air exhausting for circulation areas. As the light well communicates with the office room, the air is naturally exhausted from the lower to the upper floors as well as from the office to the circulation areas. During summer, skylights opening cause the exhaustion of hot air from the building by stack effect. An air 


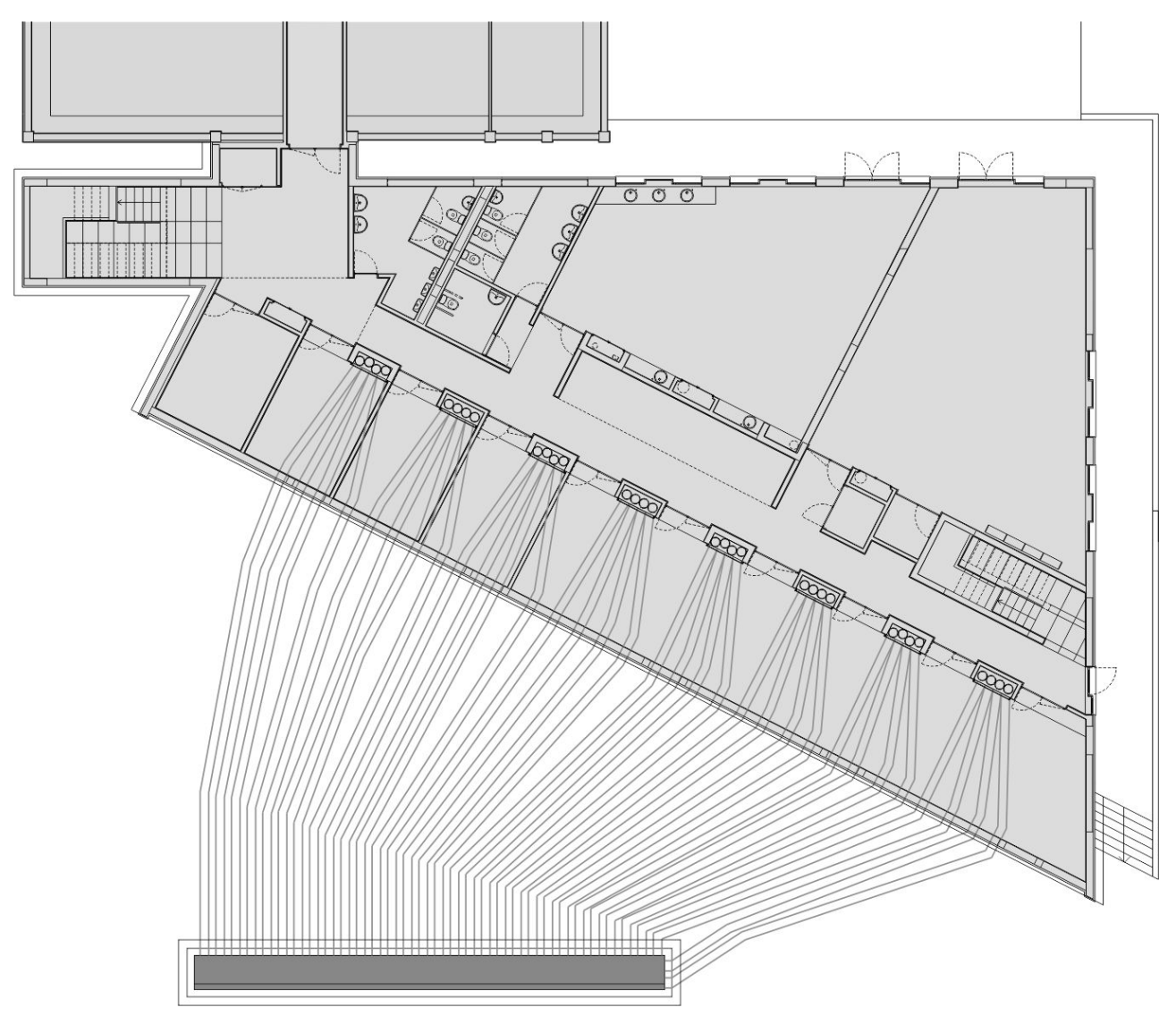

Figure 3: Semi-buried floor plan: ground-cooling pipes layout and extension.

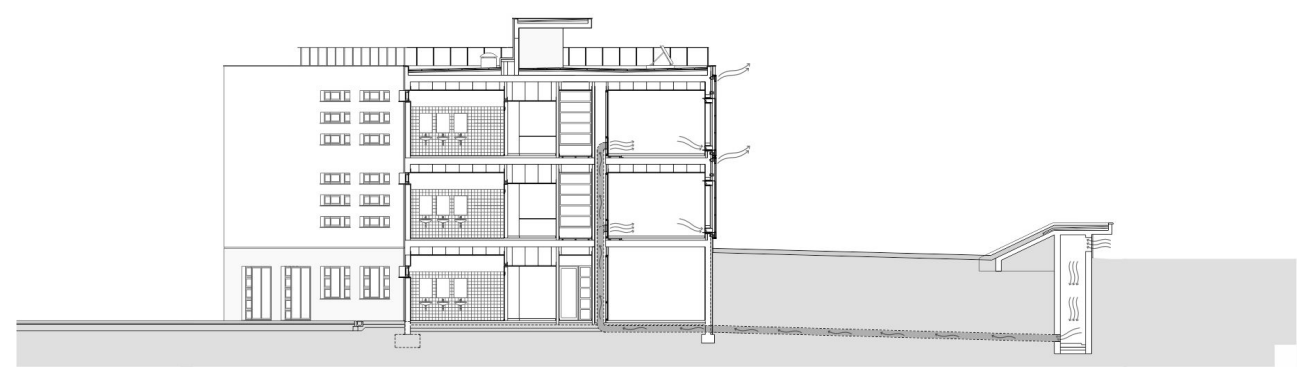

Figure 4: Building cross-section: ground-cooling ventilation of office rooms. 
temperature gradient is expected in the light well, with higher temperatures in the upper floors.

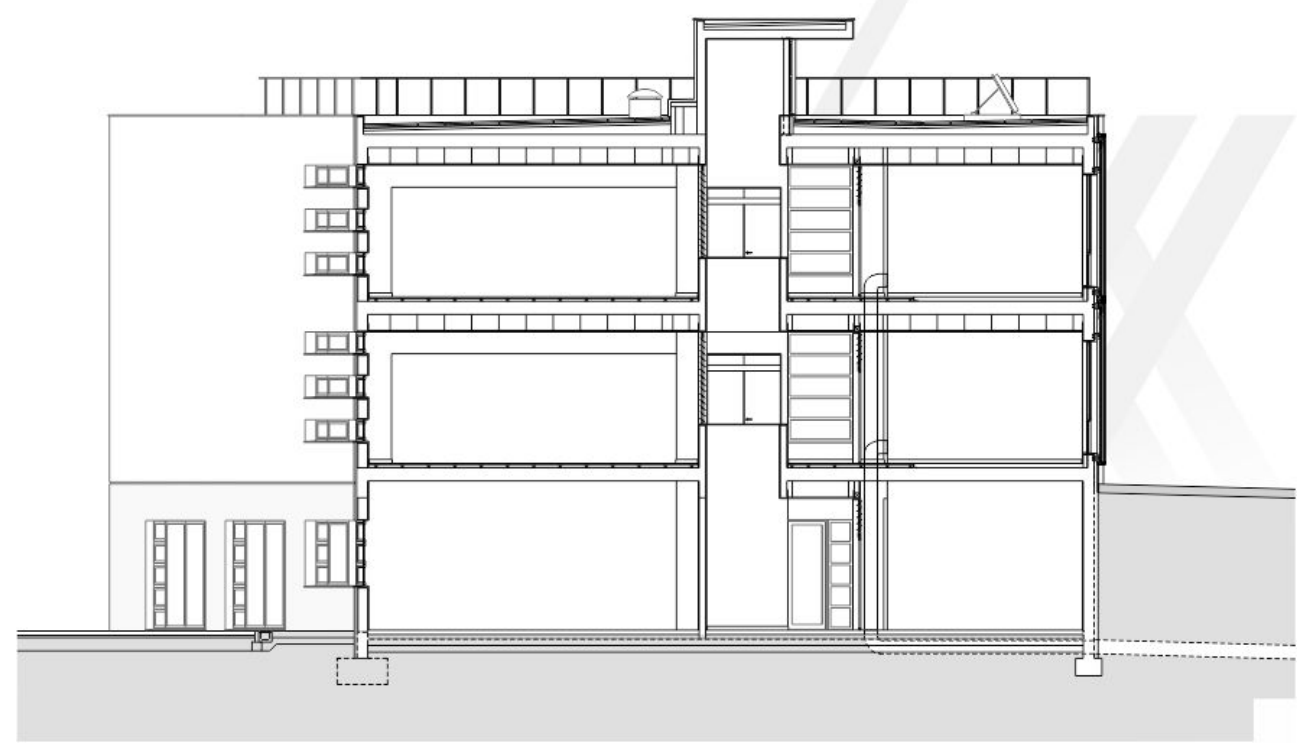

Figure 5: Building cross-section: summer solar shading.

\section{Performance of the implemented measures}

\subsection{Direct gains and shading windows}

During a three-year period (2007-2009), using the monitored days from December to February (three months of winter season), daily maximum values of room air temperature are plotted against daily maximum global solar radiation (Fig. 7a) and external air temperature (Fig. 7b). The results show that, when compared to external air temperature, global solar radiation is better correlated with the room air temperature $\left(R^{2}=0.60\right)$.

The linear trend found shows that solar gains through the window office contribute to an increase of room air temperature by $1.2^{\circ} \mathrm{C}$ for each $100 \mathrm{~W} / \mathrm{m}^{2}$ of increase on daily maximum global solar radiation. Therefore, for a winter clear-sky day (peak solar radiation higher than $600 \mathrm{~W} / \mathrm{m}^{2}$ ) it could also be expected that office air temperature may increase up to $25^{\circ} \mathrm{C}$. 


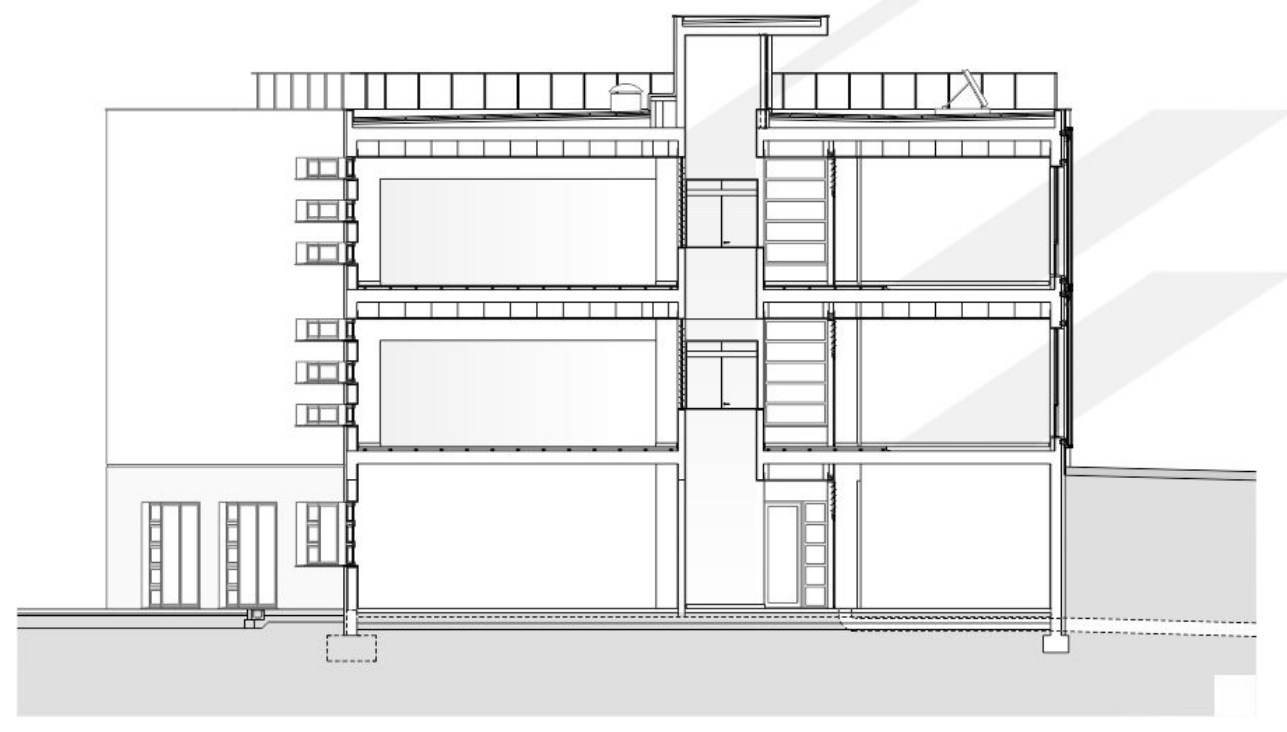

Figure 6: Building cross-section: winter direct heat and daylighting.
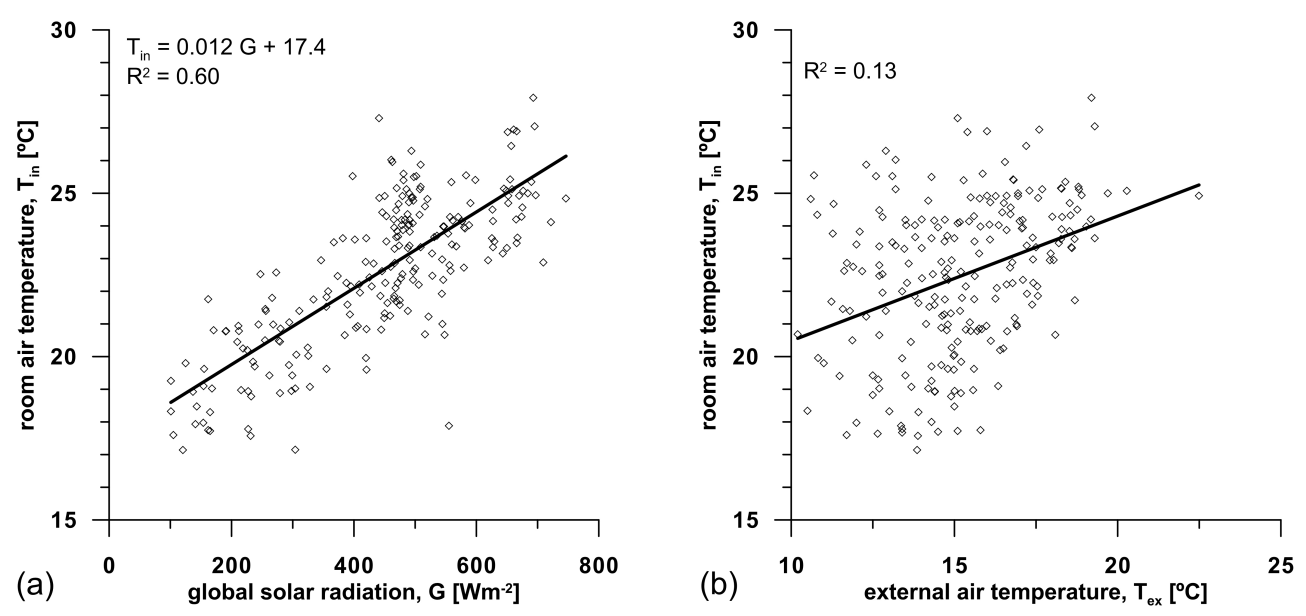

Figure 7: Correlation of maximum room air temperature with (a) maximum global solar radiation and (b) maximum external air temperature for winter period. 
Note that even during night time period indoor air temperature does not fall bellow $15^{\circ} \mathrm{C}$ (Fig. 8), so that days with low solar radiation are characterized by low room thermal amplitude.

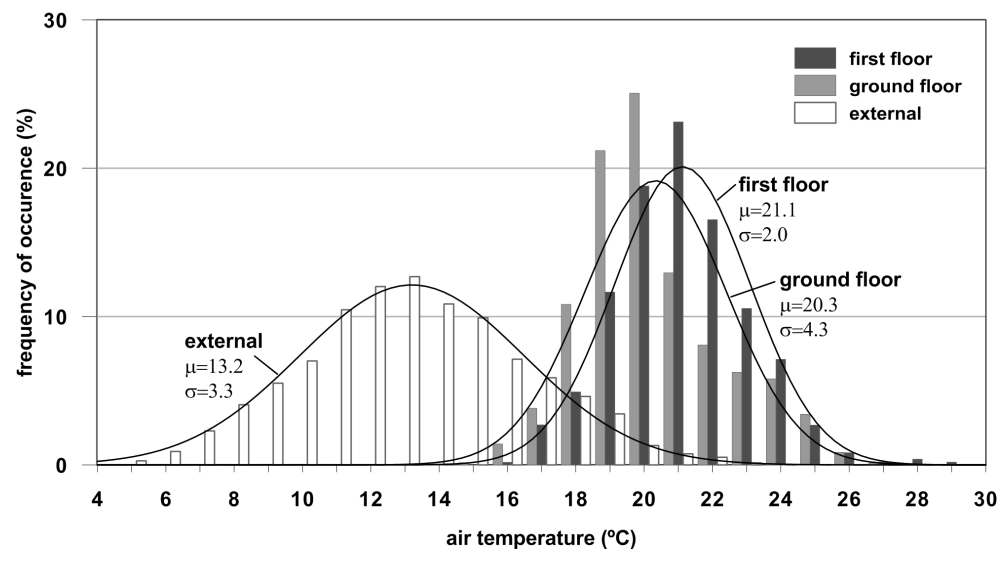

Figure 8: Distribution of external and room air temperatures for winter period.

In summer season, unlike winter, room temperature is more sensitive to the external temperature than to solar radiation as shown in Fig. 9, where measured daily maximum values are plotted for three summer months (from July to September of 2007 and 2008).

In fact, external air temperature is the parameter which best correlates with the room air temperature $\left(R^{2}=0.55\right)$. The fact that room temperature is better correlated with external temperature than to solar radiation shows that other phenomena besides solar gains, such as heat transmission and infiltration of external air, are dominant in the energy balance. These results also evidence that south windows position coupled with shading devices are sufficiently efficient for neutralizing summer solar radiation. According to the correlation obtained,

$$
T_{\text {max }, i n}=0.24 T_{\text {max }, e x}+19.8
$$

room air temperatures higher than $28^{\circ} \mathrm{C}$ would only be reached on days with a maximum external air temperatures higher than $34^{\circ} \mathrm{C}$. It is noteworthy that, as a rule of thumb, an increase of $4^{\circ} \mathrm{C}$ in the external air temperature $\left(38^{\circ} \mathrm{C}\right)$ only causes a $1^{\circ} \mathrm{C}$ increase in room air temperature.

Whereas a common criterion to evaluate comfort is that air temperature can exceed $28^{\circ} \mathrm{C}$ only in $1 \%$ of the time, it is observed during summer that 

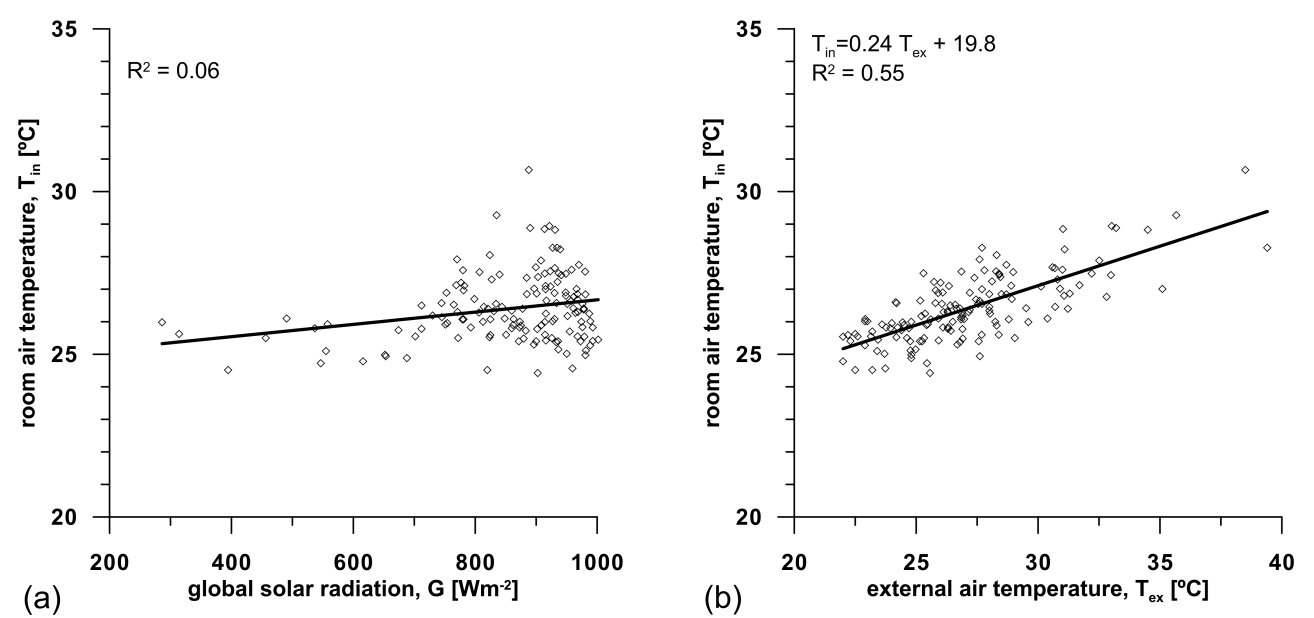

Figure 9: Correlation of room air temperature with (a) global solar radiation and (b) external air temperature for summer period.

the frequency of occurrence of values above $28^{\circ} \mathrm{C}$ is below $1 \%$ for room air temperature for both floors (Fig. 10), while for external air that threshold is exceeded $8 \%$ of the time.

\subsection{Ground-cooling system}

The complete analytical solution for the heat diffusion of a cylindrical air/soil heat-exchanger proposed by Hollmuller [11] was used to compute the expected ground-cooled air (room inlet) for a summer period of Lisbon's climate. The analytical model takes into account the pipes' diameter, pipes' depth, air flow rate and travel path. In Figure 11, daily maximum values of external $\left(T_{\max , e x}\right)$ and room inlet (air exiting the ground-cooling pipe system, $\left.T_{\text {max }, \text { in }}\right)$ air temperatures are compared. For an external temperature of $28.9^{\circ} \mathrm{C}$, the room inlet was $21.5^{\circ} \mathrm{C}$, representing an amplitude-dampening $\left(T_{\max , e x}-T_{\max , i n}\right)$ of $7.4^{\circ} \mathrm{C}$.

However, the theoretical line of Fig. 11 shows that amplitude-dampening increases with daily maximum external air temperature. The empirical expression that best correlates the analytically calculated values is

$$
T_{\text {max }, e x}-T_{\max , i n}=0.6 T_{\max , e x}-9.5
$$

For the range of daily maximum air temperatures in very hot summer days in Lisbon city $\left(28-35^{\circ} \mathrm{C}\right)$, an amplitude-dampening from 7 to $11^{\circ} \mathrm{C}$ could be expected. 


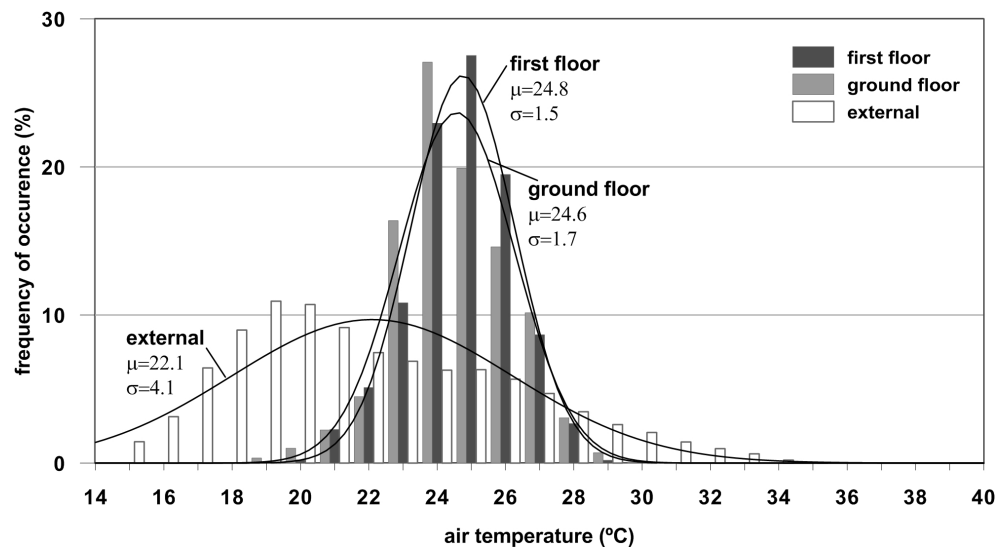

Figure 10: Distribution of external and room air temperatures for summer period.

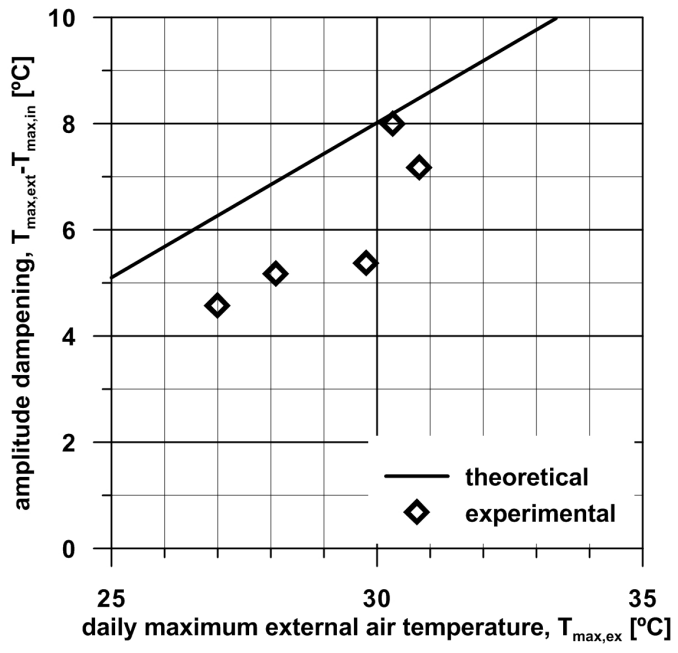

Figure 11: Amplitude-dampening of external air temperature for Lisbon climate (theoretical) and some monitoring days (experimental). 
The comparison between the model results and experimental data is compromised by the intermittent use of the ground-cooling system. However, for the period where fans are turned on (some afternoon hours during five summer days), the air is blown into the room at a temperature relatively close to the expected by Hollmuller's theoretical formulation, as shown by the experimental data plotted in Fig. 11.

\subsection{Natural ventilation}

During summer and winter periods, the air temperatures in the three floors inside the light well were measured. The differences between the daily maximum air temperatures in each floor and those in the semi-buried floor are presented in Fig. 12. In the ground and first floors the gradient is always positive for both seasons. During winter, the daily maximum air temperature in the ground floor is 1 or $2.5^{\circ} \mathrm{C}$ higher than the semi-buried floor (Fig. 12a). In the second floor the gradient is higher, with differences around 1.5 and $4.5^{\circ} \mathrm{C}$ (Fig. 12b). For both floors, during night period, differences are less than $1^{\circ} \mathrm{C}$ (not observed in Fig. 12). During summer, despite a few exceptions where differences are very small (less than $1^{\circ} \mathrm{C}$ ), the temperature gradient observed has values close to those measured in winter. Therefore, from these results it can be concluded that stratification of the air inside the light well is verified for both periods with a large intensity during daytime period.
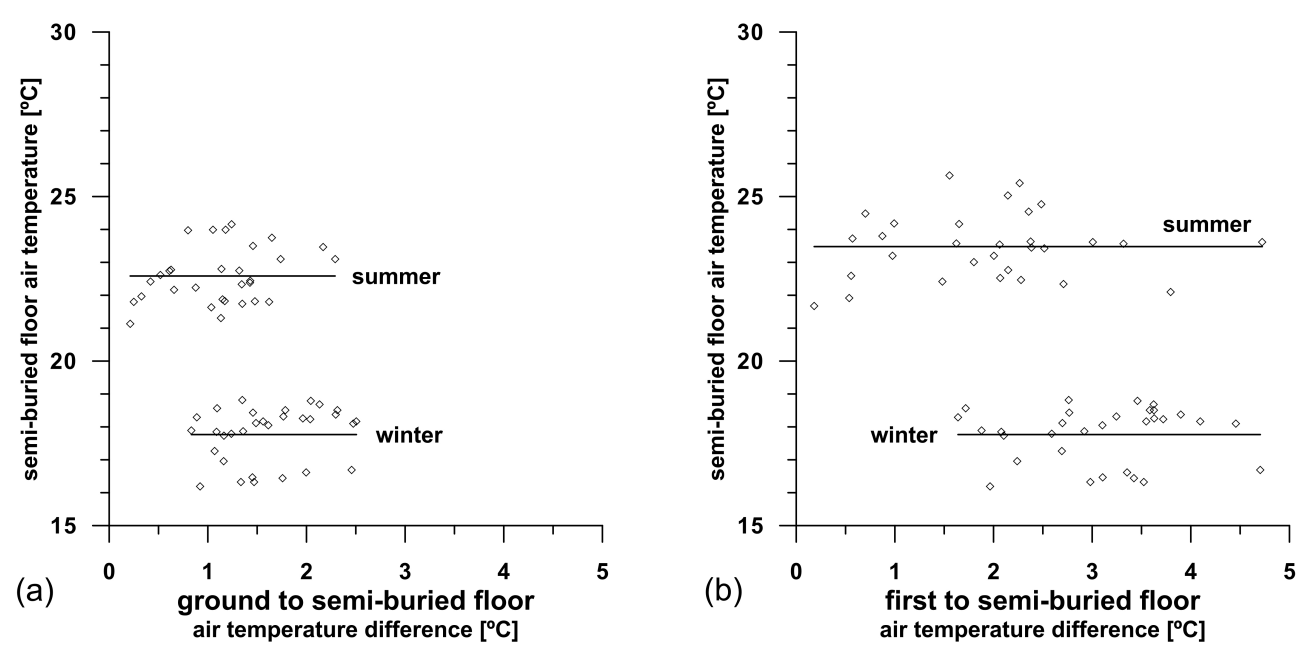

Figure 12: Air temperature gradient inside light well for (a) ground-floor and (b) first-floor. 


\subsection{Users assessment of indoor environment}

Two years after the building started operating, a survey [10] was carried out among its occupants in order to state their personal assessment of environmental working conditions inside the building. The results show that $77 \%$ of users considered the overall environment acceptable both in summer and in winter. With regard to thermal comfort in summer, $73 \%$ of users manifested that conditions were acceptable; in winter this value increased to $75 \%$. The highest percentage of users was satisfied with the conditions of lighting (83\% in summer and $91 \%$ in winter) and acoustics (91\%). In terms of indoor air quality in the summer, $83 \%$ of users were satisfied, decreasing to $77 \%$ in winter.

\subsection{Energy Consumption}

In terms of energy dependency, Solar XXI uses natural gas for heating and electricity for office equipments, lighting and other electric equipments, such as fans and pumps. Estimations based on inquiry and simulations indicate that $65 \%$ is used in office equipments, $18 \%$ in lighting, $12 \%$ for heating (natural gas boiler) and $5 \%$ in fans and pumps [13]. These percentages refer to primary energy use. It is important to emphasize that lighting use would be much higher in a standard office building without natural lighting strategies. In fact, besides some darker days or late hours, south offices and corridors rarely need electric lighting. The photovoltaic panels integrated in the south façade and on an adjacent parking lot produce about $20 \mathrm{MWh} /$ year which is $67 \%$ of the primary energy and $70 \%$ of total electricity used in the building. The above figures result in a net energy use of $36 \mathrm{kWh} / \mathrm{m}^{2}$ per year which is about $1 / 10^{\text {th }}$ of the total use of energy of a standard new office building [12] $\left(400 \mathrm{kWh} / \mathrm{m}^{2}\right)$. Solar XXI is therefore a high energy-efficient building close to a net zero energy building(NZEB), because of the very small difference between the energy consumed and that produced.

\section{Discussion and recommendations}

Office buildings generally consume high levels of energy, especially for HVAC and lighting. Passive office buildings have the mission of demonstrating that it is possible to reduce energy consumption by combining strategies of heating and passive cooling, natural ventilation and daylighting. It is noteworthy that Solar XXI, as a model building, depends greatly on local 
climate, therefore, this is something that should be taken into account in order to reproduce the concept in other locations. In fact, the most successful strategies applied into Solar XXI are the south direct gains and daylighting because of high levels of solar radiation in Lisbon. Other successful feature is the PV integration in the façade, aesthetically attractive and simultaneously optimized for winter electricity generation. This project shows that improvements would be necessary in fans acoustics as well as in the controllers for ground-cooling and vents for natural ventilation.

\section{Conclusion}

Solar XXI building has been occupied since the beginning of 2006. The three-year utilization and monitoring enabled a first proof of the passive concepts which sustain the building design. The south façade is equally divided into direct gain systems and photovoltaic panels for the production of electricity. The windows in the office rooms contribute with solar gains during winter sunny days, as shown in the correlation between solar radiation and daily maximum indoor air temperature. The effectiveness of shading devices is also proved by the correlation between daily maximums external and indoor air temperature, instead of solar radiation. Considering the small amount of monitored days where ground-cooling system worked, the air blown into the room has a temperature close to the analytical solution for the heat diffusion of a cylindrical air/soil heat-exchanger [11]. This ground-cooling system causes an amplitude-dampening of external air temperature of at least $5^{\circ} \mathrm{C}$. In terms of energy balance, this building is an example of a low energy building, consuming about 1/10th of a standard new office building, according to Portuguese legislation. Future monitoring should be orientated for the ground-cooling system functioning in order to have a more accurate assessment of its effectiveness on removing heat from the offices, as well as optimized schedules.

\section{Acknowledgments}

Building project and construction funded by European Union, FEDER, and Portuguese Ministry of Economy, Program Prime. 


\section{References}

[1] Rodrigues C, Viana S, Silva A, Joyce A, Gonçalves H. Solar XXI building PV systems: performance during the first two years of operation. In Proceedings of EuroSun Conference, 1st Intern. Confer. on Solar Heating, Cooling and Buildings (CD), Lisboa, 7-10 October 2008.

[6] Olygay V. Design with Climate. Princeton: Princeton University Press; 1963.

[2] Mazria E. The Passive Solar Energy Book: A Complete Guide to Passive Solar Home, Greenhouse and Building Design. Emmaus: Rodale Press; 1979 .

[3] Wagner R, Spieler A, Vajen K, Beisel S. Passive Solar Office Building: Results of the first Heating Period. In IES Solar World Congress, Jerusalem, 1999.

[4] Faigle B. Energon: $6000 \mathrm{~m}^{2}$ passive office building in Ulm, Germany. In Proceedings Passiefhuis-Symposium 2005. Aalst, 21 October 2005.

[5] Breescha H, Bossaerb A, Janssensa A. Passive cooling in a low-energy office building. Solar Energy 2005;79(6):682:696.

[7] Goncalves H, Oliveira M, Patricio A. How did the solar houses perform in Portugal? In Procedings of the 22nd National Passive Solar Conference, Vol.22:17-21, Washinton DC, 25-30 Apr 1997.

[8] Gonçalves H, Silva A, Ramalho A, Rodrigues C. Thermal performance of a passive solar office building. In Proceedings of EuroSun Conference, 1st Intern. Confer. on Solar Heating, Cooling and Buildings (CD), Lisboa, 7-10 October 2008.

[9] Steemers K, Environmental Issues of Building Design. In: Santamouris M, Editor, Environmental Design of Urban Buildings, Earthscan, UK; 2006.

[10] Edificio Solar XXI, Case Study nr.12, Advanced Ventilation Strategies, Building Advent IEE Project. 
[11] Hollmuller P. Analytical characterization of amplitude-dampening and phase-shifting in air/soil heat-exchangers. International Journal of Heat and Mass Transfer 2003;46:4303-4317.

[12] Decreto-Lei 79/2006. Regulamento dos Sistemas Energeticos de Climatizaçao em Edificios (in portuguese).

[13] Goncalves H, Solar XXI Towards Zero Energy, LNEG, Lisbon, Portugal; 2010. 